\title{
A unique SARS-CoV-2 spike protein P681H strain detected in Israel
}

Neta S. Zuckerman ${ }^{1,+}$, Shay Fleishon ${ }^{1}$, Efrat Bucris ${ }^{1}$, Dana Bar-llan ${ }^{1}$, Michal Linial ${ }^{2}$, Itay Bar$\mathrm{Or}^{1}$, Victoria Indenbaum ${ }^{1}$, Merav Weil ${ }^{1}$, Israel National Consortium for SARS-CoV-2 sequencing $^{\S}$, Ella Mendelson ${ }^{1,3}$, Michal Mandelboim ${ }^{1,3, *}$, Orna Mor $^{1,3, *}$.

1 Central Virology Laboratory, Israel Ministry of Health, Sheba Medical Center, TelHashomer, 52621, Israel

2 Department of Biological Chemistry, The Alexander Silberman Institute of Life Sciences, The Hebrew University of Jerusalem, Jerusalem 91904, Israel.

3 Department of Epidemiology and Preventive Medicine, School of Public Health, Sackler Faculty of Medicine, Tel-Aviv University, Tel-Aviv 69978, Israel.

* These authors contributed equally to the manuscript

\section{${ }^{+}$Corresponding author:}

Neta S. Zuckerman

Central Virology Laboratory, Israel Ministry of Health

Chaim Sheba Medical Center, Tel-Hashomer, 52621

Tel: +972-3-530-2341

email: neta.zuckerman@sheba.health.gov.il

\section{${ }^{\S}$ Israel National Consortium for SARS-CoV-2 sequencing:}

Neta Zuckerman, Efrat Dahan Bucris, Michal Mandelboim, Dana Bar-Ilan, Oran Erster, Tzvia Mann, Omer Murik, David A. Zeevi, Assaf Rokney, Joseph Jaffe, Eva Nachum, Maya Davidovich Cohen, Ephraim Fass, Gal Zizelski Valenci, Mor Rubinstein, Efrat Rorman, Israel Nissan, Efrat Glick-Saar, Omri Nayshool, Gideon Rechavi, Ella Mendelson, Orna Mor

Acknowledgments: The National Covid-19 Information \& Knowledge Center. 
medRxiv preprint doi: https://doi.org/10.1101/2021.03.25.21253908; this version posted March 28, 2021. The copyright holder for this preprint (which was not certified by peer review) is the author/funder, who has granted medRxiv a license to display the preprint in It is made available under a CC-BY-NC-ND 4.0 International license .

Abstract: Routine detection, surveillance and reporting of SARS-CoV-2 novel variants is important, as these threaten to hinder vaccination efforts. Herein we report a local novel strain that includes a non-synonymous mutation in the spike (S) protein - $\mathrm{P} 681 \mathrm{H}$ and additional synonymous mutations. The $\mathrm{P} 681 \mathrm{H}$ Israeli strain has not been associated with higher infection rates and was neutralized by sera from vaccinated individuals in comparable levels to the B.1.1.7 strain and a non-P681H strain from Israel. 
medRxiv preprint doi: https://doi.org/10.1101/2021.03.25.21253908; this version posted March 28, 2021. The copyright holder for this preprint (which was not certified by peer review) is the author/funder, who has granted medRxiv a license to display the preprint in It is made available under a CC-BY-NC-ND 4.0 International license .

\section{Introduction}

The severe acute respiratory syndrome coronavirus 2 (SARS-CoV-2) outbreak is in the midst of its third wave in Israel, with increasing efforts to sequence complete SARS-CoV-2 genomes to detect known and emerging variants. Herein we report a local novel strain that includes a non-synonymous mutation in the spike (S) protein - $\mathrm{P} 681 \mathrm{H}$ and additional synonymous mutations. The $\mathrm{P} 681 \mathrm{H}$ Israeli strain has not been associated with higher infection rates and was neutralized by sera from vaccinated individuals in comparable levels to the B.1.1.7 strain and a non-P681H strain from Israel.

\section{Results}

\section{Characterization of the Israeli P681H strain}

The $\mathrm{P} 681 \mathrm{H}$ strain presents as a cluster in a phylogenetic tree of all sequenced samples in Israel, distinct from the B.1.1.7 Pangolin lineage, which also contains the $\mathrm{P} 681 \mathrm{H}$ mutation (Figure 1A). The strain originates from the B.1.1.50 Pangolin lineage, in which the majority of the sequences are from Israel (70\%), Palestine (12\%) and the UK (12\%) [1]. It is characterized by a non-synonymous mutation in the S protein - $\mathrm{P} 681 \mathrm{H}$ (C23604A) and additional four synonymous mutations: Nsp3:C7765T, Nsp12b:C13821T, Nsp16:T21111C and C29545A. The strain carrying these mutations is unique to Israel, aside for 2 sequences originating in Palestine. A sub-clade of the strain contains an additional non-synonymous mutation in the S protein - A27S (G21641T) (Figure 1B). 
medRxiv preprint doi: https://doi.org/10.1101/2021.03.25.21253908; this version posted March 28, 2021. The copyright holder for this preprint (which was not certified by peer review) is the author/funder, who has granted medRxiv a license to display the preprint in It is made available under a CC-BY-NC-ND 4.0 International license .

A

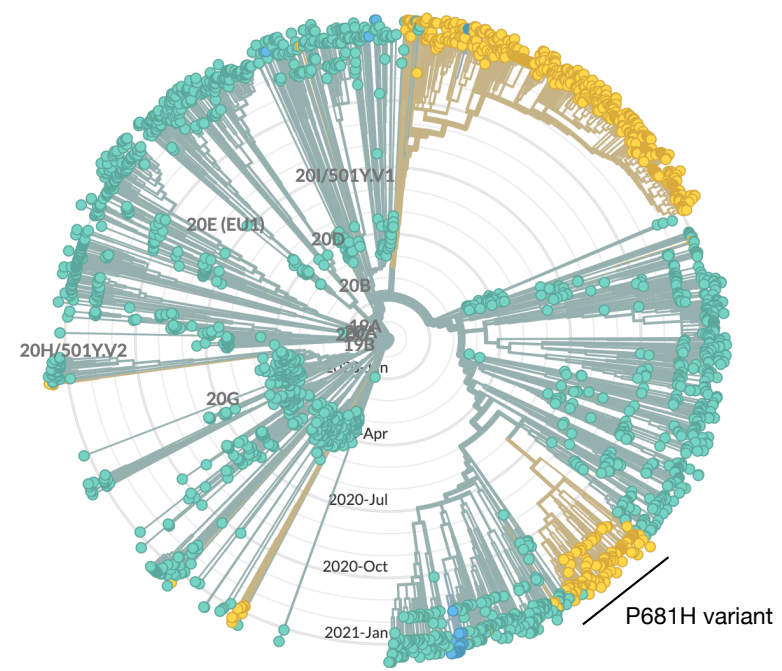

Genotype at S site 681

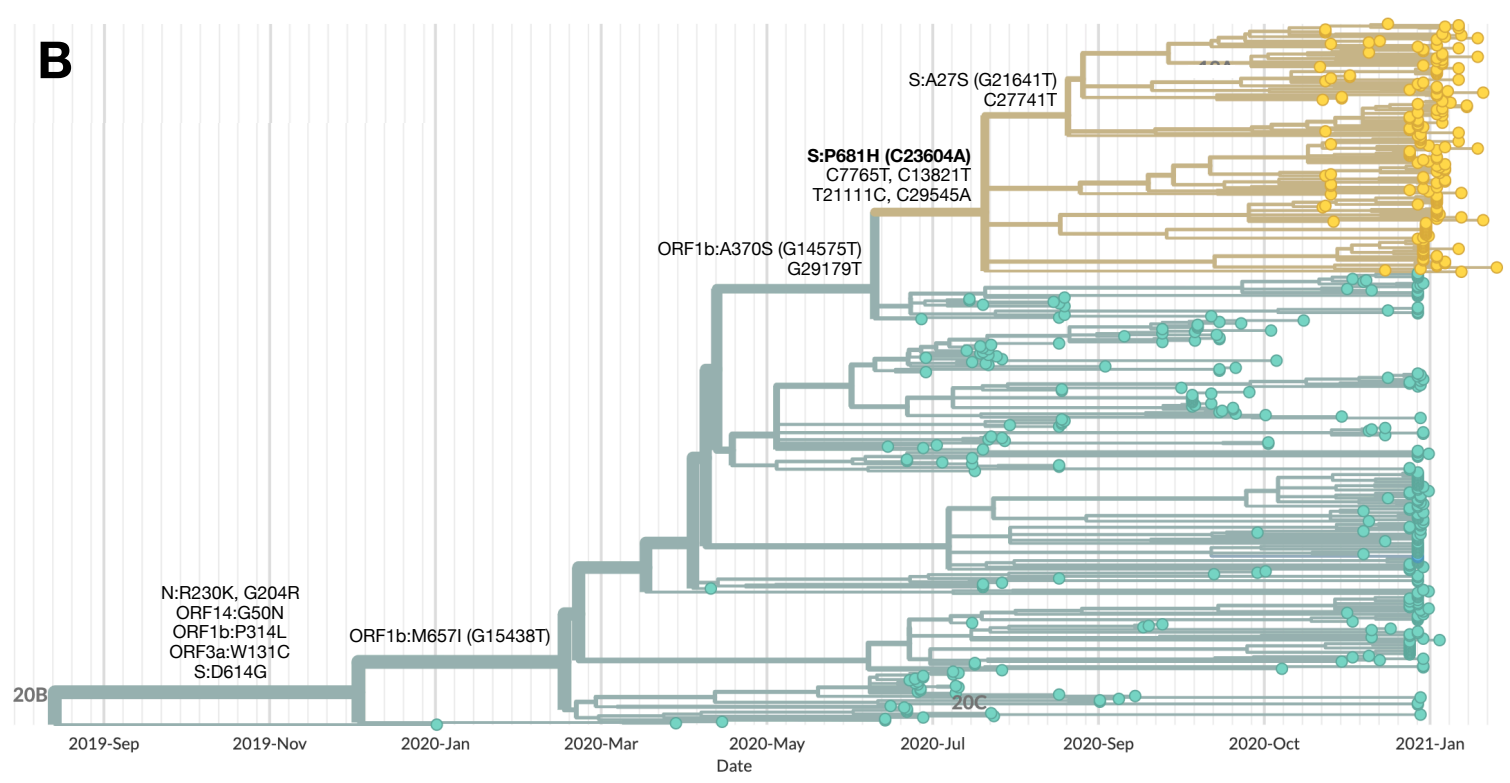

Figure 1. Characterization of $\mathrm{P} 681 \mathrm{H}$ strain in Israel within the B.1.1.50 lineage

Phylogenetic trees highlighting the genotype at site 681 in the S protein, with the wild-type proline

$(P)$ in green and the mutations histidine $(H)$ and arginine $(R)$ in yellow and blue, respectively. (A)

SARS-CoV-2 whole genomes sequenced in Israel from March 2020 to January 2021 ( $n=2482)$. The main clusters harboring the $\mathrm{P} 681 \mathrm{H}$ mutation are the B.1.1.7 (20I/501Y.V1) and the $\mathrm{P} 681 \mathrm{H}$ variant.

(B) SARS-CoV-2 whole genomes of the B.1.1.50 lineage $(n=489)$. The P681H cluster is composed of local viruses only, and of 2 sequences from isolates identified in Palestine, and includes a sub-cluster with an additional S protein non-synonymous mutation, A27S. Phylogenetic trees were created with Nextstrain Augur pipeline and visualized with Auspice [2]. Non-Israeli B.1.1.50 lineage sequences were identified with using Pangolin [1] and downloaded from GISAID. 
medRxiv preprint doi: https://doi.org/10.1101/2021.03.25.21253908; this version posted March 28, 2021. The copyright holder for this preprint (which was not certified by peer review) is the author/funder, who has granted medRxiv a license to display the preprint in It is made available under a CC-BY-NC-ND 4.0 International license.

Until January 2021, an overall of 181 individuals were infected with the $\mathrm{P} 681 \mathrm{H}$ strain. These were mostly randomly sampled from districts from all over Israel, with no gender or age bias (Table 1).

\begin{tabular}{|ll|ccc|}
\hline & & November & December & January \\
\hline gender & Male & 10 & 30 & 25 \\
& Female & 8 & 24 & 23 \\
& Unknown & 9 & 17 & 35 \\
\hline age & & $39.3 \pm 21.3$ & $33.8 \pm 25.3$ & $35.8 \pm 22$ \\
\hline reason & random & 27 & 55 & 80 \\
& outbreaks & & 10 & \\
& ret. abroad & & 6 & 3 \\
\hline district & Northern & 3 & 7 & 14 \\
& Haifa & 4 & 2 & 5 \\
& Central & 4 & 19 & 32 \\
& Tel Aviv & 1 & 11 & 10 \\
& Jerusalem & 1 & 9 & 9 \\
& Jud \& Sam & 1 & & 5 \\
& Southern & 1 & 4 & 3 \\
& Unknown & 12 & 19 & 5 \\
\hline total & & 27 & 71 & 83 \\
\hline
\end{tabular}

Table 1. Epidemiology of $\mathrm{P} 681 \mathrm{H}$ Israeli variant. Frequency and patient-related information of the $\mathrm{P} 681 \mathrm{H}$ Israeli strain. Ret. abroad is return from abroad; Jud \& Sam is Judea and Samaria.

\section{Identification of P681H mutation in sewage}

The P681H mutation was also frequently identified by SARS-CoV-2 whole genome sequencing of samples from waste-water treatment plants in 9 locations across Israel, that were collected once a month, August 2020 - January 2021 (Figure 1). As the P681H mutation is also found in the B.1.1.7 variant, its frequency has increased in some locations since late December 2020, following the first introduction of B.1.1.7 into Israel. Notably, the mutation was already observed with 5\% frequency as early as October 2020 in Rahat (city in the South of Israel) and in November, at a frequency of $98 \%$ in Natanya and Haifa, located at the center and north of Israel, respectively (Figure 2). 
medRxiv preprint doi: https://doi.org/10.1101/2021.03.25.21253908; this version posted March 28, 2021. The copyright holder for this preprint (which was not certified by peer review) is the author/funder, who has granted medRxiv a license to display the preprint in It is made available under a CC-BY-NC-ND 4.0 International license .

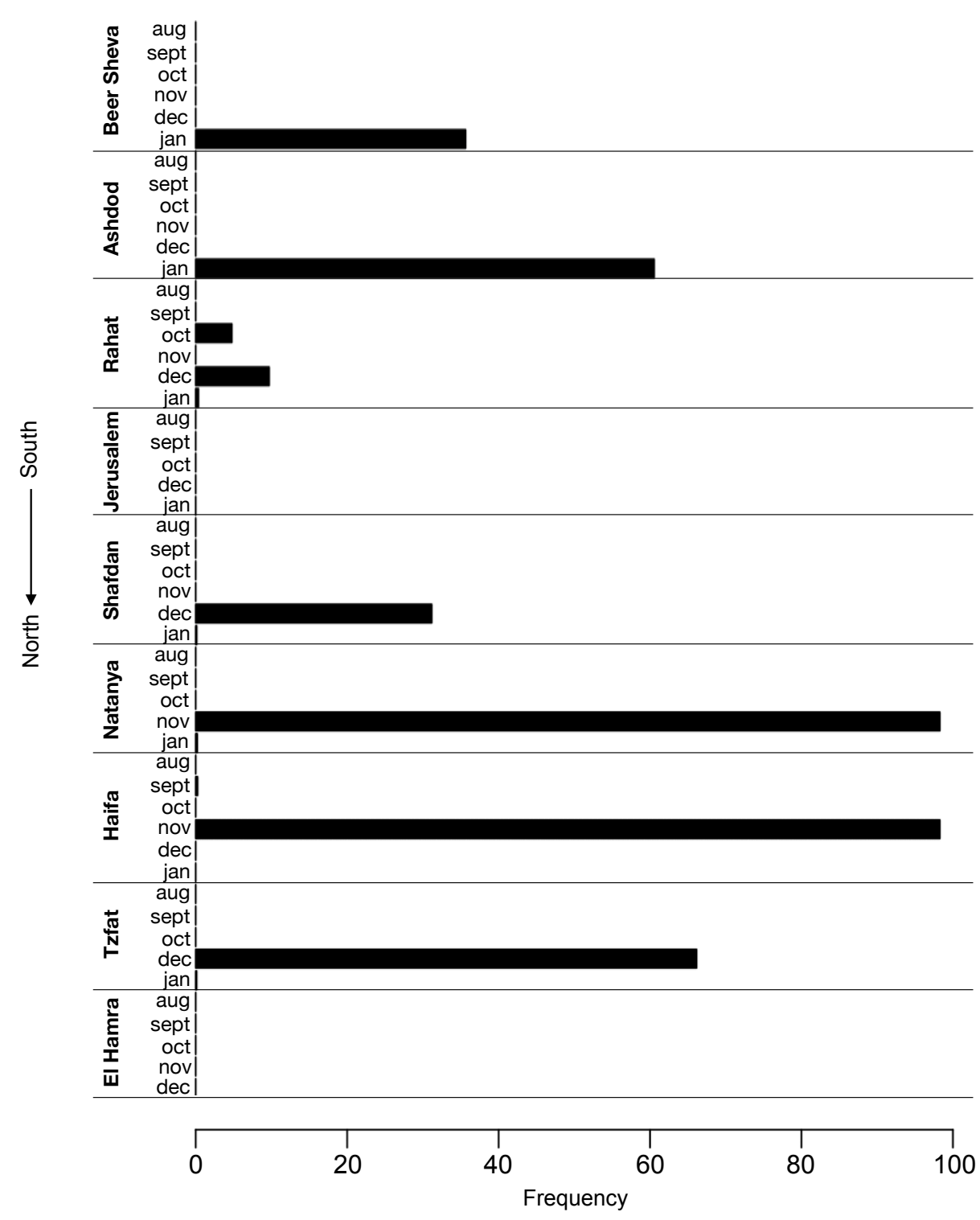

Figure 2. Identification of the $\mathrm{P} 681 \mathrm{H}$ mutation in sewers across Israel. Frequency of $\mathrm{P} 681 \mathrm{H}$ mutation in SARS-CoV-2 genomes sequenced from 9 wastewater treatment plants across Israel each month in August 2020 - January 2021. The frequency of the P681H mutation in each region was estimated by measuring the fraction of the mutation from the total number of nucleotides mapped to the position (i.e., depth of sequencing).

\section{Effective neutralization of the $\mathrm{P} 681 \mathrm{H}$ strain}

The neutralization potency of antibodies against the local $\mathrm{P} 681 \mathrm{H}$ strain was compared to the neutralization of other strains circulating in Israel. VERO-E6 cells were infected with (a) Israeli P681H strain (isolate hCoV-19/Israel/CVL-45176-P681H-ngs/2020), (b) non-P681H strain from Israel (isolate hCoV-19/Israel/CVL-45526-ngs/2020) and (c) B.1.1.7 strain (isolate hCoV-19/Israel/CVL-46879-ngs/2020). The different strains were pre-incubated with serial 
medRxiv preprint doi: https://doi.org/10.1101/2021.03.25.21253908; this version posted March 28, 2021. The copyright holder for this preprint (which was not certified by peer review) is the author/funder, who has granted medRxiv a license to display the preprint in It is made available under a CC-BY-NC-ND 4.0 International license .

dilutions of serum samples obtained from individuals vaccinated with two doses of the Pfizer vaccine. Results demonstrate comparable neutralization of the sera against the P681H Israeli strain, the B.1.1.7 strain and the non-P681H strain (Figure 3).

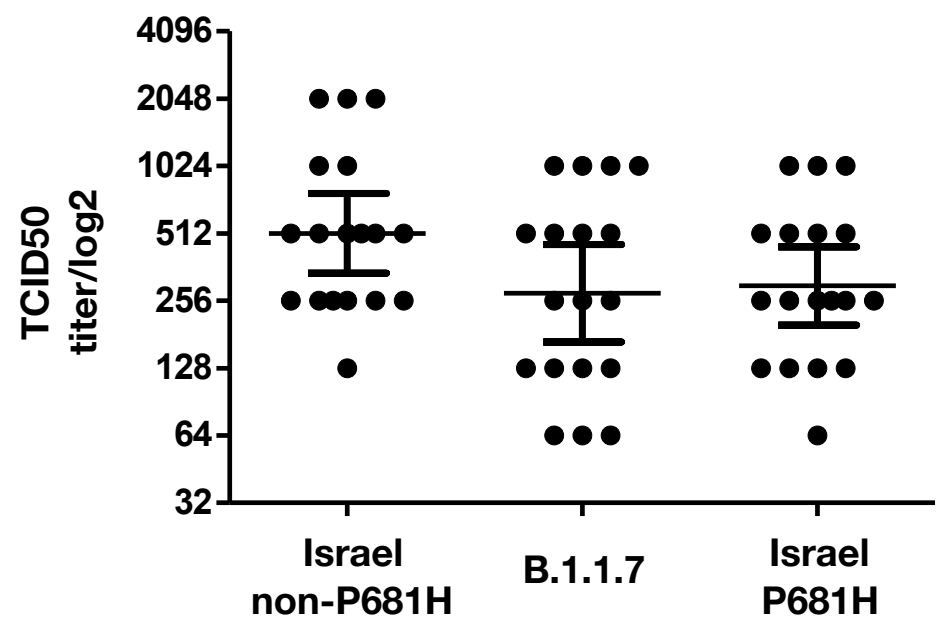

Figure 3. Neutralization of the P681H Israeli strain. Neutralization assays were carried out with VERO-E6 cells infected with the P681H Israeli strain, B.1.1.7 strain and non-P681H strain from Israel, using sera from vaccinated individuals. On day 6 , plates were colorized overnight with Gentian violet $+4 \%$ formaldehyde solution for virus neutralization. Titers were calculated by qualitative measurements of the cytopathic effect for each patient. Bars represent the geometric mean titer (GMT) and 95\% confidence intervals.

\section{Discussion and conclusions}

The P681H mutation has been observed as early as March 2020 in samples worldwide, e.g. in Nigeria [3] and Hawaii [4] and also characterizes the globally spreading B.1.1.7 variant. Herein, we report 181 sequences that are part of the B.1.1.50 lineage, but form a unique local strain that harbors the $\mathrm{P} 681 \mathrm{H}$ mutation along with additional defining mutations. The P681H strain has been identified in clinical samples since November 2020, however the P681H mutation has been identified in Israel already in October 2020 via SARS-CoV-2 wastewater sequencing.

The $\mathrm{P} 681 \mathrm{H}$ is located in the vicinity of the furin cleavage site in the S protein. It is postulated to enhance transmissibility of the virus by facilitating a conformational change in the $\mathrm{S}$ protein following protease activity at the cell membrane [3]. Previous serum neutralization 
medRxiv preprint doi: https://doi.org/10.1101/2021.03.25.21253908; this version posted March 28, 2021. The copyright holder for this preprint (which was not certified by peer review) is the author/funder, who has granted medRxiv a license to display the preprint in It is made available under a CC-BY-NC-ND 4.0 International license .

assays for VSV-based SARS-CoV-2 pseudoviruses expressing the S protein with the $\mathrm{P} 681 \mathrm{H}$ mutation demonstrated no significant changes in the titer required for neutrazliation compared to the unmutated S protein [4]. Additionally, no significant changes in the titer were needed for neutralization of the WT SARS-CoV-2 compared to a viral sample from the B.1.1.7 lineage (in which $\mathrm{P} 681 \mathrm{H}$ is one of its defining mutations), using sera from convalescent patients or individuals vaccinated with the mRNA-1273 vaccine from Moderna [5]. Similar to these reports, this study demonstrates comparable neutralization of the $\mathrm{P} 681 \mathrm{H}$ Israel strain, non-P681H strain and the B.1.1.7 variant by sera from vaccinated individuals.

Overall, as the $\mathrm{P} 681 \mathrm{H}$ local strain was neutralized as efficiently as commonly circulating strains, was not associated with escalated infection or spread and given that the $\mathrm{P} 681 \mathrm{H}$ mutation is observed in additional SARS-CoV-2 strains worldwide, this emerging local variant is currently not defined as a variant of concern. Nevertheless, it is still monitored by routine next generation sequencing in Israel. 
medRxiv preprint doi: https://doi.org/10.1101/2021.03.25.21253908; this version posted March 28, 2021. The copyright holder for this

preprint (which was not certified by peer review) is the author/funder, who has granted medRxiv a license to display the preprint in

It is made available under a CC-BY-NC-ND 4.0 International license

\section{Methods}

\section{Sample collection for sequencing}

Random sampling and collection of SARS-CoV-2 PCR-positive samples for sequencing complete viral genomes is routinely conducted in Israel as part of a national effort for monitoring SARS-CoV-2 variants, starting December 2020.

\section{Library preparation and sequencing}

Viral genomes were extracted from $200 \mu$ l respiratory samples with the MagNA PURE 96 (Roche, Germany), according to the manufacturer instructions. Libraries were prepared using COVID-seq library preparation kit, as per manufacturer's instructions (Illumina). Library validation and mean fragment size was determined by TapeStation 4200 via DNA HS D1000 kit (Agilent). Libraries were pooled, denatured and diluted to 10pM and sequenced on NovaSeq (Illumina).

\section{Bioinformatics analysis}

Fastq files were subjected to quality control using FastQC

(www.bioinformatics.babraham.ac.uk/ projects/fastqc/) and MultiQc [6] and low-quality sequences were filtered using trimmomatic [7]. Sequences were mapped to the SARS-CoV-2 reference genomes (NC_045512.2) using Burrows-Wheeler aligner (BWA) mem [8].

Resulting BAM files were sorted, indexed and subjected to quality control using SAMtools suite [9]. Coverage and depth of sequencing was calculated from sorted bam files using a custom python script. A consensus sequence was constructed for each sample using iVar (https://andersen-lab.github.io/ivar/html/index.html), where positions with $<5$ nucleotides were determined as Ns, and converted to a fasta file using seqtk (https://github.com/lh3/seqtk). Sequences were aligned to SARS-CoV-2 reference genome (NC_045512.2) using MAFFT [10].

Mutation calling, translation to amino acid and identification of $\mathrm{P} 681 \mathrm{H}$ variant sequences were done in R with a custom code using Bioconductor package Seqinr [11]. Sequences were further analyzed together with additional sequences identified as belonging to the background lineage B.1.1.50 downloaded from GISAID [12]. 
medRxiv preprint doi: https://doi.org/10.1101/2021.03.25.21253908; this version posted March 28, 2021. The copyright holder for this preprint (which was not certified by peer review) is the author/funder, who has granted medRxiv a license to display the preprint in It is made available under a CC-BY-NC-ND 4.0 International license .

Phylogenetic trees were constructed using the Augur pipeline [2]. Sequences were aligned to SARS-CoV-2 reference genome (NC_045512.2) using MAFFT [10], and a time-resolved phylogenetic tree was constructed with IQ-Tree [13] and TreeTime [14] under the GTR substitution model and visualized with auspice [2]. Lineage nomenclature was attained from Pangolin Lineages [15].

Analysis of sewage samples was conducted using a custom R code and the Bioconductor package Rsamtools [16]. BAM files were imported to $R$ and the frequency of each mutated position along the genome, out of the total number of nucleotides covering that position, was obtained. The frequency in position 681 in the spike protein was recorded for each sample.

\section{Neutralization assays}

VERO-E6 cells at concentration of $20 * 103 /$ well were seeded in sterile 96 -wells plates with $10 \%$ FCS MEM-EAGLE medium, and stored at $37^{\circ} \mathrm{C}$ for 24 hours. One hundred TCID50 of $\mathrm{P} 681 \mathrm{H}$ variant, non- $\mathrm{P} 681 \mathrm{H}$ and B.1.1.7 isolates were incubated with inactivated sera diluted 1:10 to 1:1280 in 96 well plates for 60 minutes at 33으. Virus-serum mixtures were added to the Vero E-6 cells and incubated for five days at $33^{\circ} \mathrm{C}$, after which Gentain violet staining (1\%) was used to stain and fix the cell culture layer. Neutralizing dilution of each serum sample was determined by identifying the well with the highest serum dilution without observable cytopathic effect. A dilution equal to 1:10 or above was considered neutralizing. 
medRxiv preprint doi: https://doi.org/10.1101/2021.03.25.21253908; this version posted March 28, 2021. The copyright holder for this preprint (which was not certified by peer review) is the author/funder, who has granted medRxiv a license to display the preprint in It is made available under a CC-BY-NC-ND 4.0 International license .

\section{References}

[1] A. Rambaut et al., "A dynamic nomenclature proposal for SARS-CoV-2 lineages to assist genomic epidemiology," Nat. Microbiol., vol. 5, no. 11, pp. 1403-1407, Nov. 2020, doi: 10.1038/s41564-020-0770-5.

[2] J. Hadfield et al., "Nextstrain: real-time tracking of pathogen evolution," Bioinformatics, vol. 34, no. 23, pp. 4121-4123, Dec. 2018, doi:

10.1093/bioinformatics/bty407.

[3] B. Coutard, C. Valle, X. de Lamballerie, B. Canard, N. G. Seidah, and E. Decroly, "The spike glycoprotein of the new coronavirus 2019-nCoV contains a furin-like cleavage site absent in CoV of the same clade.," Antiviral Res., vol. 176, p. 104742, 2020, doi: 10.1016/j.antiviral.2020.104742.

[4] D. D. H. Pengfei Wang, Lihong Liu, Sho Iketani, Yang Luo, Yicheng Guo, Maple Wang, Jian Yu, Baoshan Zhang, Peter D. Kwong, Barney S. Graham, John R. Mascola, Jennifer Y. Chang, Michael T. Yin, Magdalena Sobieszczyk, Christos A. Kyratsous, Lawrence Shapiro, Zizhang, "Increased Resistance of SARS-CoV-2 Variants B.1.351 and B.1.1.7 to Antibody Neutralization," bioRxiv, 2021, doi:

https://doi.org/10.1101/2021.01.25.428137.

[5] for the C.-19 N. S. G. Venkata Viswanadh Edara, Katharine Floyd, Lilin Lai, Meredith Gardner, William Hudson, Anne Piantadosi, Jesse J. Waggoner, Ahmed Babiker, Rafi Ahme, "Infection and mRNA-1273 vaccine antibodies neutralize SARS-CoV-2 UK variant," medRxiv, 2021, doi: https://doi.org/10.1101/2021.02.02.21250799.

[6] P. Ewels, M. Magnusson, S. Lundin, and M. Käller, "MultiQC: Summarize analysis results for multiple tools and samples in a single report," Bioinformatics, vol. 32, no. 19, pp. 3047-3048, 2016, doi: 10.1093/bioinformatics/btw354.

[7] A. M. Bolger, M. Lohse, and B. Usadel, "Trimmomatic: a flexible trimmer for Illumina sequence data.," Bioinformatics, vol. 30, no. 15, pp. 2114-20, Aug. 2014, doi: 10.1093/bioinformatics/btu170.

[8] H. Li and R. Durbin, "Fast and accurate long-read alignment with Burrows-Wheeler transform," Bioinformatics, vol. 26, no. 5, pp. 589-595, 2010, doi: 10.1093/bioinformatics/btp698. 
medRxiv preprint doi: https://doi.org/10.1101/2021.03.25.21253908; this version posted March 28, 2021. The copyright holder for this preprint (which was not certified by peer review) is the author/funder, who has granted medRxiv a license to display the preprint in It is made available under a CC-BY-NC-ND 4.0 International license .

[9] H. Li, "A statistical framework for SNP calling, mutation discovery, association mapping and population genetical parameter estimation from sequencing data," Bioinformatics, vol. 27, no. 21, pp. 2987-2993, 2011, doi:

10.1093/bioinformatics/btr509.

[10] K. Katoh, "MAFFT: a novel method for rapid multiple sequence alignment based on fast Fourier transform," Nucleic Acids Res., vol. 30, no. 14, pp. 3059-3066, Jul. 2002, doi: 10.1093/nar/gkf436.

[11] C. Delphine and L. Jean R., "SeqinR 1.0-2: A Contributed Package to the R Project for Statistical Computing Devoted to Biological Sequences Retrieval and Analysis," in Structural Approaches to Sequence Evolution, Springer: Berlin/Heidelberg, Germany, 2007, pp. 207-232.

[12] Y. Shu and J. McCauley, "GISAID: Global initiative on sharing all influenza data - from vision to reality.," Euro Surveill., vol. 22, no. 13, 2017, doi: 10.2807/15607917.ES.2017.22.13.30494.

[13] L.-T. Nguyen, H. A. Schmidt, A. von Haeseler, and B. Q. Minh, "IQ-TREE: a fast and effective stochastic algorithm for estimating maximum-likelihood phylogenies.," Mol. Biol. Evol., vol. 32, no. 1, pp. 268-74, Jan. 2015, doi: 10.1093/molbev/msu300.

[14] P. Sagulenko, V. Puller, and R. A. Neher, "TreeTime: Maximum-likelihood phylodynamic analysis," Virus Evol., vol. 4, no. 1, Jan. 2018, doi: 10.1093/ve/vex042.

[15] A. Rambaut et al., "A dynamic nomenclature proposal for SARS-CoV-2 lineages to assist genomic epidemiology.," Nat. Microbiol., vol. 5, no. 11, pp. 1403-1407, 2020, doi: 10.1038/s41564-020-0770-5.

[16] N. H. Martin Morgan, Hervé Pagès, Valerie Obenchain, "Rsamtools: Binary alignment (BAM), FASTA, variant call (BCF), and tabix file import." 2020. 